\title{
Phosphorus limitation affects the molecular composition of Thalassiosira weissflogii leading to increased biogenic silica dissolution and high degradation rates of cellular carbohydrates
}

\author{
Panagiotopoulos Christos ${ }^{1,}{ }^{\star}$, Goutx Madeleine ${ }^{1}$, Suroy Maxime ${ }^{1}$, Moriceau Brivaela ${ }^{2}$
}

\begin{abstract}
${ }^{1}$ Aix Marseille Univ., Université de Toulon, CNRS, IRD, Mediterranean Institute of Oceanography (MIO) UM 110, 13288, Marseille, France

2 Université de Brest, Institut Universitaire Européen de la Mer (IUEM), CNRS, Laboratoire des

Sciences de l'Environnement Marin, UMR 6539 CNRS/UBO/IFREMER/IRD, 29280 Plouzané, France

* Corresponding author: Christos Panagiotopoulos, email address :

christos.panagiotopoulos@mio.osupytheas.fr
\end{abstract}

\begin{abstract}
:
Diatoms in general, and Thalassiosira weissflogii ( $T$. weissflogii) in particular, are among the most ubiquitous phytoplanktonic species while, phosphorus $(P)$ is an essential nutrient that limits productivity in many oceanic regimes. To investigate how $T$. weissflogii cultures grown under different $P$ regimes are chemically altered before and during their prokaryotic degradation, T. weissflogii cells were cultivated under two contrasting $\mathrm{P}$ conditions, "P-stress" and "P-replete". Biodegradation experiments were conducted in natural sea water comprising a natural prokaryotic community. The particulate fraction was monitored for 3 weeks for organic carbon (POC), nitrogen (PON), biogenic silica (bSiO2), total carbohydrates $(\mathrm{PCHO})$ and individual monosaccharides, including prokaryotic counting. Our results indicated that P-stress induced changes in the chemical composition of the T. weissflogii cells, causing a decrease to the $\mathrm{Si} / \mathrm{N}(1.1$ to 0.46$)$ and $\mathrm{Si} / \mathrm{C}(0.17$ to 0.08$)$ ratios. The "P-stress $\mathrm{T}$. weissflogii" cells were characterized by high amounts of galactose $(23 \%$ of $\mathrm{PCHO})$, xylose $(21 \%)$, and glucose $(19 \%)$ compared to the "P-replete T. weissflogii" cells, which were dominated by ribose $(20 \%$ of $\mathrm{PCHO})$, further indicating the exhaustion of ribose-rich molecules (e.g., ATP) in T. weissflogii under "P-stress" conditions. The degradation experiments showed that bSiO2 produced under "P-stress" conditions dissolved more rapidly than bSiO2 formed under "P-replete" conditions, whereas POC and PON exhibited higher degradation rate constants in the "P-replete T. weissflogii" than in the "P-stress T. weissflogii" experiment. Overall, these observations show that $\mathrm{T}$. weissflogii submitted to P-limitation, results in changes in its initial biochemical composition, increases frustule dissolution rate, and decreases the degradation of $\mathrm{T}$. weissflogii-organic matter by marine prokaryotes.
\end{abstract}




\section{Highlights}

- Effect of P-stress on the T.weissflogii initial carbohydrate and silica composition. High degradation of particulate organic carbon and nitrogen of $T$. weissflogii under P- replete conditions. High degradation of particulate carbohydrates of $T$. weissflogii under P-stress conditions. High dissolution of biogenic silica of $T$. weissflogii under P-stress conditions.

Keywords : Bacterial biodegradation, Thalassiosira weissflogii, P-stress, POC, PON, Carbohydrates, biogenic silica. 


\section{Introduction}

Nitrogen $(\mathrm{N})$ and phosphorus $(\mathrm{P})$ are among the most important nutrients in terrestrial and aquatic ecosystems. The former is mainly involved in the production of plant and animal tissues (protein synthesis), whereas the latter is fundamental in many biological processes as well as in structural components of cells (e.g., RNA and DNA, energy transactions via ATP; Lehninger et al., 1993; Berg et al., 2002; Karl and Björkman, 2015). Although $\mathrm{N}$ and $\mathrm{P}$ belong to the same group of elements on the periodic table and they both contribute to eutrophication phenomena (i.e., act as fertilizers; Ryther and Dunstan, 1971; Gruber and Galloway, 2008; Némery and Garnier, 2016), they exhibit different oxidation states, have different uptake pathways (e.g., $\mathrm{N}$ can be retrieved from the atmosphere by diazotrophs), and their N/P ratio may span from $<16$ to $>100$ (Vitousek and Howarth, 1991; Downing, 1997; Paytan and McLaughlin, 2007; Godwin and Cotner, 2015; Karl and Björkman, 2015). Although the $\mathrm{N}$ and $\mathrm{P}$ cycles are closely linked to one another, $\mathrm{P}$ appears to be more critical as a limiting element (Trommer et al., 2013). This is not only because of its low proportions compared to $\mathrm{N}$, but also because it cannot be found in the atmosphere in a gaseous state (Paytan and McLaughlin, 2007; Karl and Björkman, 2015). Therefore, the availability of $\mathrm{P}$ is critical for cell growth in marine ecosystems, especially for phytoplankton (Redfield et al., 1963; Jackson and Williams, 1985; Thingstad et al., 2005; Paytan and McLaughlin, 2007). 
Despite the fact that $\mathrm{P}$ sources in seawater are numerous, whether in inorganic or organic forms (Karl and Björkman, 2015), phytoplanktonic organisms very often cannot grow and eventually turn over as a result of P-stress. P-stress conditions have been observed in different parts of the ocean, including the China Sea (Harrison et al., 1990a), the northwestern Mediterranean Sea (Thingstad et al., 2005), and the western North Atlantic Ocean (Wu et al., 2000). Several studies have assessed the impact of Pstarvation stress in phytoplankton in terms of cellular growth; P-competition with other species, including bacteria; the extracellular release of organic compounds; and the biosynthesis of intracellular organic compounds (Urbani et al., 2005; Zohary et al., 2005; Moore et al., 2008; Tanaka et al., 2011; Sebastian et al., 2016). Furthermore, other studies showed that the phytoplankton in the ocean uses non-phosphorus lipids in response to P scarcity stress (Van Mooy et al., 2009; Obata et al., 2013; Brembu et al., 2017). All these studies show the importance of $P$ on structuring the ocean phytoplankton community and on the metabolism of microalgae cells. Despite this wealth of information on P-stress on phytoplankton species, the subsequent degradation of phytoplankton grown under P-stress is a research topic that has not been thoroughly examined until now in the scientific literature. Thus, despite the fact that several studies have focused on the degradation of phytoplankton and sinking marine particles by following their bulk individual components (e.g., proteins, carbohydrates, lipids, etc.; Harvey et al., 1995; Harvey and Macko, 1997; Panagiotopoulos et al., 2002; Goutx et al., 2007; Engel et al., 2009) for 2-3 weeks, very little is known on the chemical alteration of frustules, including the silica dissolution and decomposition rates of $\mathrm{P}$ stress grown diatoms that further impact the export of photosynthetic carbon. Indeed, biogeochemical models predict a future increase in nutrient limitation across most of the 
ocean (Bopp et al., 2005). Consequently, it is important to study whether P-stress grown diatoms have the potential to be rapidly mineralized or accumulated within the dissolved organic matter pool or marine sediments, which further determines the time scale at which mineralized diatom carbon will reach the atmosphere.

The present study aims to examine the prokaryotic degradation and the frustule dissolution, and thus, the fate of marine diatoms that are previously grown under different P-conditions ("P-replete" and "P-stress"). In this study we followed the changes in the chemical composition of a very well-known diatom species, Thalassiosira weissflogii, by monitoring particulate organic carbon (POC), organic nitrogen $(\mathrm{PON})$, biogenic silica $\left(\mathrm{bSiO}_{2}\right)$, and total carbohydrates $(\mathrm{PCHO})$ over a period of 3 weeks. In contrast to previous investigations that estimated degradation rates on 3day to 1-week experiments (Goutx et al., 2007; Wetz et al., 2008; Piontek et al., 2009), we chose this unusual long-term degradation experiment recognizing that dead diatoms may reside for a long period of time in the ocean and especially in the bathypelagic layers (Agusti et al., 2015). It is important to note that a 3-week degradation experiment requires that the starting conditions must contain a high amount of diatom cells in order to follow their different pools (i.e., $\mathrm{POC}, \mathrm{PON}, \mathrm{PCHO}$, and $\mathrm{bSiO}_{2}$ ), which is only feasible using a dense diatom culture (Sun et al., 1993; Suroy et al., 2015). At the molecular level, the effect of P-stress on the degradation rate constants of the individual monosaccharides was also evaluated. The results are compared and discussed along with the bulk degradation features of the POC, $\mathrm{PON}, \mathrm{bSiO}_{2}$ and $\mathrm{PCHO}$.

\section{Materials and Methods}

\subsection{Experimental design}


The experimental protocol used in this study has been set up to follow the impact of P-stress on the degradation of the different pools of organic and inorganic matter (POC, $\mathrm{PON}$, and $\mathrm{bSiO}_{2}$ ), including the $\mathrm{PCHO}$ in dead diatoms, for 3 weeks. We used T. weissflogii as a model diatom as this ubiquitous species has extensively been studied in terms of transparent polymer production (Chen et al., 2015), aggregation and sedimentation (Seebah et al., 2014), growth rates under N- and Si- starvation (De La Rocha et al., 2010; Suroy et al., 2015), and photosynthetic efficiency under P-stress (Liu et al., 2011). A schematic view of the experimental protocol employed in this study is presented in Fig. 1. Briefly, T. weissflogii cells were grown under two different conditions, namely, "P-replete T. weissflogii" (control condition) and "P-stress $T$. weissflogii". Thalassiosira weissflogii cells were then killed and inoculated in $0.7 \mu \mathrm{m}$ filtered seawater containing its natural prokaryotic community, to monitor the net degradation for 3 weeks.

\subsubsection{Preparation of "P-replete" and "P-stress" T. weissflogii cultures}

The marine ubiquitous diatom T. weissflogii (strain CCMP 1049) was obtained from the IFREMER facility (Argenton station, France), and the initial culture in $\mathrm{f} / 2$ medium was treated with a mix of antibiotics, including penicillin G, streptomycin, and gentamycin, to remove bacteria (Guillard, 2005). The absence of bacteria was checked by placing the inoculum on ZoBell agar plates (ZoBell, 1941). The $\mathrm{PO}_{4}{ }^{3-}$ starvation experiments were undertaken in a $10 \mathrm{~L}$ batch culture by switching the medium supply from normal f/2 to a $\mathrm{PO}_{4}{ }^{3-}$-free $\mathrm{f} / 2$ medium (Guillard and Ryther, 1962; Fig. 1). As such, two $10 \mathrm{~L}$ culture batches were prepared: one "P-stress $T$. weissflogii" batch and one "P-replete $T$. weissflogii" batch. Both axenic cultures in batches were maintained 
for 1 week at $18{ }^{\circ} \mathrm{C}\left( \pm 1{ }^{\circ} \mathrm{C}\right)$ under a light/dark cycle $(16 \mathrm{~h}: 8 \mathrm{~h})$ under a photon flux density of $180 \mu \mathrm{mol}$ photons $\mathrm{m}^{-2} \mathrm{~s}^{-1}$. The impact of P-stress on T. weissflogii cells was evaluated by monitoring the photosynthetic parameters using fluorescence (WATER/B - PAM, Walz, Effeltrich, Germany; Schreiber et al., 1986) and Fourier-transform infrared spectroscopy (Tensor 27 BRUKER; Beardall et al., 2001). The maximum energy conversion efficiency or quantum efficiency of photosystem II charge separation (Fv/Fm) decreased from 0.6 to 0.3 on day 7 . At this time, the maximum photosynthetic electron transport rate $\left(\mathrm{ETR}_{\max }\right)$ obtained from light curves relating the ETR to the irradiance decreased from 2.9 to 0.013 , indicating that "P-stress $T$. weissflogii" cells were not able to maintain photosynthesis after 7 days (Soler, 2010). The FTIR spectra of the entire cells also showed significant changes in the $T$. weissflogii cell structure under P-stress conditions (Fig. S1). The T. weissflogii cell numbers obtained in the $10 \mathrm{~L}$ batches after this treatment were approximately $1.8 \times 10^{8}$ cell $\mathrm{L}^{-1}$ for both cultures ("Preplete $T$. weissflogii" and "P-stress $T$. weissflogii"). The $T$. weissflogii cultures were then concentrated by centrifugation (20 min at $2000 \mathrm{rpm}$ ), the supernatant was discarded, and the pellets were frozen at $-80{ }^{\circ} \mathrm{C}$ for $24 \mathrm{~h}$ to kill T. weissflogii without breaking their cells (Soler, 2010; Fig. 1).

\subsubsection{Degradation experiment}

The pellets of the $T$. weissflogii cells grown in the two different treatments ("Preplete" and "P-stress") were resuspended in $12 \mathrm{~L}$ degradation batches that were filled with $0.7 \mu \mathrm{m}$ filtered natural seawater sampled at a depth of $10 \mathrm{~m}$ in the Bay of Brest. The final $T$. weissflogii cell concentration was similar in the two degradation batches (Table 1) and large enough to ensure a clear signal for all the measured parameters until 
the end of the 3 week degradation experiment (see below). The nitrate, phosphate, and silicate concentrations in seawater on the day of sampling were $0.33,0.05$, and 0.66 $\mu \mathrm{M}$, respectively. The seawater temperature was $15.8^{\circ} \mathrm{C}$, which was almost identical to that used for the incubation experiments (see below). The seawater was filtered at 0.7 $\mu \mathrm{m} \mathrm{GF} / \mathrm{F}$ (47 mm, Whatman; baked at $450{ }^{\circ} \mathrm{C}$ for $6 \mathrm{~h}$ ) to remove phyto- and zooplanktonic organisms while maintaining most of the natural prokaryotic community (Duhamel et al., 2007; Suroy et al., 2015).

The prokaryotic inoculum concentrations were estimated before the addition of T. weissflogii. Thalassiosira weissflogii cellular concentrations were estimated on day 1 , considering that $24 \mathrm{~h}$ are necessary for $T$. weissflogii cells to adapt to the new medium (prokaryotes plus dead T. weissflogii cells), resulting in a homogenous mixture for sampling. Hence, we considered that the degradation experiment started $24 \mathrm{~h}$ after the setup of the degradation batches, assuming that there was little variability in the POC, $\mathrm{PON}, \mathrm{bSiO}_{2}$, and $\mathrm{PCHO}$ concentrations between day 0 and day 1 of the experiment. Thus, the ratio of these parameters to the $T$. weissflogii cells did not change dramatically in this time interval. The degradation batches were placed on an orbital shaker table at $16{ }^{\circ} \mathrm{C}$ in the dark, and punched caps were used to ensure gas exchange. The batches were sampled daily for their biochemical parameters (POC, $\mathrm{PON}, \mathrm{bSiO}_{2}$, and $\mathrm{PCHO}$ ), including the total counts of heterotrophic prokaryotes over 21 days. Replicate samples $(n=2-3)$ were taken throughout the degradation experiments, mainly on days $2,6,9$, 12, and 19, depending on the experiment (see also figure captions). Prior to each sampling, the batches were gently shaken to ensure homogeneity. At the end of the experiment, approximately $40 \%$ of the initial volume remained in the bottle to minimize batch effects. 


\subsection{Prokaryotic and T. weissflogii cell counts}

Prokaryotes were counted on $5 \mathrm{~mL}$ samples at each time point by flow cytometry using a FacsVerse flow cytometer (Becton Dickinson, San Jose, USA). Data from the flow cytometer were processed using the BD FacSuite ${ }^{\mathrm{Tm}}$ software, according to previously described methods (Troussellier et al., 1993; Marie et al., 1997; Marie and Partensky, 2006). The T. weissflogii cell numbers were also measured by flow cytometry on the first day of the biodegradation experiment to obtain information about the initial T. weissflogii concentrations.

\subsection{POC and PON analysis}

Each day, a $10 \mathrm{~mL}$ sample from each of the degradation batches ("P-replete" and "P-stress") was collected and filtered on $0.7 \mu \mathrm{m}$ precombusted GF/F filters $\left(450^{\circ} \mathrm{C}, 6\right.$ h) for POC and PON concentration measurements. The filters were dried overnight in an oven at $50{ }^{\circ} \mathrm{C}$. The POC and PON levels were measured on the same filter using a Carlo Erba NA 2100 CN analyzer coupled with a Finnigan Delta S mass spectrometer (Nieuwenhuize et al., 1994). The detection limits were $5 \mu \mathrm{g}$ and $1 \mu \mathrm{g}$ for POC and PON, respectively, with a standard error of $2-3 \%$.

\section{4. $\mathrm{SiO}_{2}$ analysis}

To monitor the $\mathrm{bSiO}_{2}$ dissolution, each day $10 \mathrm{~mL}$ samples from each of the degradation batches were filtered on $0.45 \mu \mathrm{m}$ polycarbonate filters. Filtrates were directly analyzed for dissolved silica (dSi; see below), whereas filters were dried overnight and used for $\mathrm{bSiO}_{2}$ analysis using a variation of the method of Ragueneau and Tréguer (1994). Following this protocol, the filters were digested in $0.2 \mathrm{~N} \mathrm{NaOH}$ during 
$4 \mathrm{~h}$ at $95^{\circ} \mathrm{C}$, then the solutions were cooled in ice, neutralized using $1 \mathrm{~N} \mathrm{HCl}$, and centrifuged to remove remaining solids. As no lithogenic silica was present in the algal culture, the second digestion step using HF was omitted. The overlying water was analyzed for $\mathrm{dSi}$ using the molybdate blue spectrophotometric method adapted by Gordon et al. (1993) for use in segmented flow colorimetry. Standards were made in distilled water for $\mathrm{bSiO}_{2}$ analysis and artificial seawater for $\mathrm{dSi}$. The analysis was performed on a Bran and Luebbe Technicon Autoanalyzer ( $<1 \%$ precision).

\subsection{PCHO analysis}

Similar to the POC, $\mathrm{PON}$, and $\mathrm{bSiO}_{2}$ measurements, a $10 \mathrm{~mL}$ sample from each of the degradation batches was collected and filtered on $0.7 \mu \mathrm{m}$ pre-combusted GF/F filters $\left(450^{\circ} \mathrm{C}, 6 \mathrm{~h}\right)$ for the $\mathrm{PCHO}$ analysis using the procedure described by Suroy et al. (2015). Briefly, filters were cut with clean scissors, transferred into glass tubes, and hydrolyzed with $1.2 \mathrm{M} \mathrm{H}_{2} \mathrm{SO}_{4}$ for $3 \mathrm{~h}$ at $100{ }^{\circ} \mathrm{C}$ (Panagiotopoulos and Wurl, 2009). The samples were neutralized with pre-combusted $\mathrm{CaCO}_{3}\left(450{ }^{\circ} \mathrm{C}\right.$ for $\left.6 \mathrm{~h}\right)$ and were pipetted into scintillation vials for liquid chromatography analysis (Suroy et al., 2015).

A Dionex ICS-3000 anion exchange chromatograph fitted with a pulsed amperometric detector (HPAEC-PAD) was used for all PCHO analyses. Details of the analytical procedure have been provided elsewhere (Panagiotopoulos et al., 2012; Suroy et al., 2015). Ten individual monosaccharides were detected in the hydrolysates of the particulate organic material, including deoxysugars (fucose and rhamnose), pentoses (arabinose, ribose, and xylose), one amino sugar (glucosamine), hexoses (galactose, glucose, and mannose), and one acidic sugar (galacturonic acid). The neutral and amino sugars were separated with an isocratic $19 \mathrm{mM} \mathrm{NaOH}$ elution at $17^{\circ} \mathrm{C}$, whereas 
galacturonic acid was detected in a separate analysis using a gradient elution (Panagiotopoulos et al., 2012). The flow rate was set at $0.7 \mathrm{~mL} \mathrm{~min}{ }^{-1}$ for neutral and acidic sugar analyses. The data acquisition and processing procedures were performed using the software Chromeleon ${ }^{\circledR}$. The analytical errors calculated by the coefficients of variation of the repeated injections of a standard solution of $50 \mathrm{nM} /$ sugar were $5-10 \%$ and $0.9-2.0 \%(n=6)$ for the peak area and retention time, respectively. The total particulate carbohydrate concentrations $(\mu \mathrm{M})$ are given in C-equivalents and the relative abundances (mol\%) of their monomeric constituents (e.g., monosaccharides) are given in Table 2.

\subsection{Statistical analysis and estimation of kinetic parameters}

The degradation of bulk organic matter ( $\mathrm{POC}$ and $\mathrm{PON}), \mathrm{bSiO}_{2}$ dissolution, PCHO, and individual monosaccharides were monitored using a statistical comparison of three mechanistic models.

Model 1 is a simple first-order exponential rate equation (1) as described by Greenwood et al. (2001), that has been used in many dissolution/degradation studies (e.g., Kamatani and Riley, 1979; Kamatani et al., 1980; Kamatani, 1982):

$$
\hat{\mathrm{C}}_{(\mathrm{t})}=\mathrm{C}_{0} \cdot \mathrm{e}^{(-k \cdot \mathrm{t})}
$$

where:

$\hat{\mathrm{C}} \mathrm{t}$ is the concentration $(\mu \mathrm{M})$ estimated at time $\mathrm{t}(\mathrm{d})$,

$\mathrm{C}_{0}$ is the initial concentration, and

$k$ is the dissolution/degradation rate constant $\left(\mathrm{d}^{-1}\right)$.

Model 2 is a second-order equation (2) that considers two pools of organic matter with different reactivities. It is similar to the equation that was used by Westrich 
and Berner (1984) for carbon degradation, and more recently it has also been employed for $\mathrm{bSiO}_{2}$ dissolution (Moriceau et al., 2009; Boutorh et al., 2016):

$$
\hat{\mathrm{C}}_{(\mathrm{t})}=\mathrm{C}_{1} \cdot \mathrm{e}^{\left(-k_{1} \cdot \mathrm{t}\right)}+\mathrm{C}_{2} \cdot \mathrm{e}^{\left(-k_{2} \cdot \mathrm{t}\right)}
$$

where:

$\hat{\mathrm{C}} \mathrm{t}$ is the concentration $(\mu \mathrm{M})$ estimated at time $\mathrm{t}(\mathrm{d})$,

$\mathrm{C}_{1}$ and $\mathrm{C}_{2}$ are the initial concentrations $(\mu \mathrm{M})$ of pools 1 and 2 , respectively, and $\mathrm{k}_{1}$ and $\mathrm{k}_{2}$ are their respective degradation rate constants $\left(\mathrm{d}^{-1}\right)$.

As equation (2) uses more parameters, Model 2 always produces a better fit than Model 1. It was found that for most of the examined parameters (i.e., POC, PON, and PCHO), the second degradation rate constant (i.e., $k_{2}$ ) was equal to zero. In this case, the model only has 3 variables: $\mathrm{C}_{1}, \mathrm{C}_{2}$, and $k_{1}$ (see equation $2 \mathrm{~b}$ ).

$$
\hat{\mathrm{C}}_{(\mathrm{t})}=\mathrm{C}_{1} \cdot \mathrm{e}^{\left(-k_{1} \cdot \mathrm{t}\right)}+\mathrm{C}_{2}
$$

The best model was chosen using the Shapiro-Wilk and Constant Variance Test statistical tests in Sigmaplot, which favors the goodness of fit and the lowest number of parameters. Likewise, the bulk parameters (POC and PON) and $\mathrm{PCHO}$ were best modeled using equation ( $2 \mathrm{~b}$ ), whereas individual monosaccharides and $\mathrm{bSiO}_{2}$ were best modeled using equations (1) and/or 2(b) (Tables 3, 4).

\section{Results}

\subsection{Initial observations}

At the beginning of the biodegradation experiment, the diatom cell concentrations were $6.60 \times 10^{7}$ cell $\mathrm{L}^{-1}$ in the "P-replete $T$. weissflogii" degradation batch and $6.80 \times 10^{7}$ cells $\mathrm{L}^{-1}$ in the "P-stress $T$. weissflogii" degradation batch (Table 
1). These concentrations are similar to those observed during a simulated $T$. weissflogii bloom (Diekmann et al., 2009) but an order of magnitude higher than those generally observed in "natural" bloom concentrations (Grattepanche et al., 2011; Smetacek, 1985).

The results indicated that the "P-stress $T$. weissflogii" growth conditions induced increases of $29 \%(\mathrm{~mol} \%)$ in the carbon and $44 \%(\mathrm{~mol} \%)$ in nitrogen per cell compared to the "P-replete $T$. weissflogii" conditions. On the other hand, $\mathrm{bSiO}_{2}$ showed the opposite trend as it was lower in the "P-stress T. weissflogii" degradation batches than in the "P-replete T. weissflogii" degradation batches (Table 1).

In this study, POC and PON values (Table 1) were not corrected for prokaryotic carbon and nitrogen because only free and not attached prokaryotes were counted. Nevertheless, the POC and PON values presented here fall within the same order of magnitude as those generally reported for T. weissflogii species (Waite et al., 1992; De La Rocha et al., 2010) and agree well with the results of a previous study of the same species in which corrections for prokaryotic carbon and nitrogen were made (Suroy et al., 2015).

Prokaryotic concentrations were measured after $24 \mathrm{~h}$ in both the "P-replete $T$. weissflogii" and "P-stress T. weissflogii" degradation batches. The results showed that the prokaryotic concentrations were similar $\left(5.6\right.$ and $7.0 \times 10^{10}$ cell $\left.\mathrm{L}^{-1}\right)$ for the "P-stress T. weissflogii" and "P-replete T. weissflogii" batches at the beginning of the experiments and that they peaked on day 1 (Table 1; Fig. 2). After day 1, prokaryotic concentrations slowly decreased to reach their first plateau on day $5\left(2.5\right.$ and $3.1 \times 10^{10}$ cell $\mathrm{L}^{-1}$ for the "P-stress $T$. weissflogii" and "P-replete T. weissflogil" batches, respectively) and a second plateau on day $12\left(3.3\right.$ and $3.7 \times 10^{10}$ cell $\mathrm{L}^{-1}$ for the "P- 
stress $T$. weissflogii" and "P-replete $T$. weissflogii" batches, respectively) until the end of the experiment (Fig. 2). Such prokaryotic features observed during biodegradation experiments agree with previous results performed in sinking marine particles (Panagiotopoulos et al., 2002; Panagiotopoulos and Sempéré, 2007), Skeletonema marinoi (Moriceau et al., 2009), Emiliania huxleyi calcium carbonate frustule (Engel et al., 2009), and Si/N- stress T. weissflogii (Suroy et al., 2015), indicating that the decrease in the particulate organic matter pool is the result of prokaryotic respiration and growth.

The results of the degradation experiment in the "P-replete T. weissflogii" batch show increases in POC and PON concentrations (of approximately 50\% and 60\% for POC and PON, respectively), which were observed between $\mathrm{T}_{0}$ and $\mathrm{T}_{2}$ (Fig. 3). A similar pattern has already been observed in other studies and is probably due to reaggregation of the $<0.7 \mu \mathrm{m}$ pool related to the addition of the prokaryotic community, which boosts the stickiness of the exopolymeric compounds (EPS) excreted by the $T$. weissflogii (Gärdes et al., 2010) as well as the heterogeneity in the batch (Suroy et al., 2015). In addition, $\mathrm{PCHO}$, glucose, and galactose, which are known to be the main constituent of the EPS copiously secreted by diatoms (Magaletti et al. 2004; Urbani et al. 2005), also increased between $\mathrm{T}_{0}$ and $\mathrm{T}_{2}$ in the "P-replete $T$. weissflogii" batches, which further reinforces the hypothesis of re-aggregation (Fig. 4b; Fig.5). After $\mathrm{T}_{2}$, the POC and PON concentrations decreased over time, which typically reflected the decomposition patterns of T. weissflogii-POC and T. weissflogii-PON (Fig. 3). In contrast to the "P-replete T. weissflogii" batch, the POC and PON concentrations in the "P-stress T. weissflogii" batch began to decrease at $\mathrm{T}_{0}$. 
Contrarily, as minute or no $\mathrm{bSiO}_{2}$ is associated with the organic matter that reaggregates in the colloidal pool, the $\mathrm{bSiO}_{2}$ concentrations remained rather stable in the "P-replete T. weissflogil" batch during the first days of the experiment (Fig. 4a). Similar to $\mathrm{POC}$ and $\mathrm{PON}, \mathrm{bSiO}_{2}$ concentrations also began to decrease at $\mathrm{T}_{0}$ in the "P-stress $T$. weissflogii" batch (Fig. 4a). The degradation of all the biochemical compounds is expressed in our study as its decrease relative to its highest concentration measured before the degradation/dissolution started.

Similar to POC, the initial concentration of the PCHO-C in the "P-stress $T$. weissflogii" degradation batch was higher than in the "P-replete T. weissflogii" degradation experiment (169 vs. $110 \mu \mathrm{MC}$; Table 2). At $\mathrm{T}_{0}, \mathrm{PCHO}$ represented 14 and $16 \%$ of POC for the "P-replete T. weissflogii" and "P-stress T. weissflogii" degradation experiments, respectively, indicating the slight preferential allocation of photosynthetic carbon into T. weissflogii cells under "P-stress" conditions (Table 2). As for POC and PON, the PCHO-C concentrations also peaked at $\mathrm{T}_{2}$ (Fig. 4b) for the "P-replete $T$. weissflogii" experiment, supporting the previously mentioned hypothesis regarding DOM aggregation.

Qualitatively, the sugar composition recorded in T. weissflogii comprised three aldohexoses, three aldopentoses, two deoxysugars, one aminosugar, and one uronic acid (see above; Table 2). Five monosaccharides generally dominated the T. weissflogii carbohydrate composition namely, galactose, glucose, xylose, ribose, and mannose. These monosaccharides accounted for $65 \%$ and $78 \%$ of PCHO in the "P-replete $T$. weissflogii" and "P-stress T. weissflogii" degradation batches, respectively, at the beginning of the biodegradation experiment. It is worth noting that the "P-replete" batch 
was particularly enriched with ribose $(\sim 20 \%)$ and galacturonic acid $(2 \%)$ when compared to the "P-stress" batch (Table 2).

\subsection{Organic matter degradation}

\subsubsection{Bulk parameters ( $\mathrm{POC}, \mathrm{PON}$, and $\mathrm{bSiO}_{2}$ )}

The POC and PON degradation followed similar patterns in both batches, with an initial period of degradation (approximately 7-8 days from the beginning of the experiment) in which the $T$. weissflogii-organic matter degraded faster, followed by a second period in which the $T$. weissflogii-organic matter concentrations remained constant (Fig. 3a). The best fits for the degradation of the POC and PON were obtained using equation $2 b$.

The $k_{l}$ degradation rate constant of POC was two times higher in the "P-replete T. weissflogii" batch than in the "P-stress T. weissflogii" batch $\left(0.40 \pm 0.05 \mathrm{~d}^{-1}\right.$ vs. 0.19 $\pm 0.05 \mathrm{~d}^{-1}$; Table 4$)$. The results showed that after $7-8$ days of degradation, approximately $36 \%$ of the POC from the "P-replete" experiment was decomposed, whereas this amount was slightly higher for the "P-stress" experiment (approximately $43 \%$ ) over the same period (Fig. 3a). Then, POC concentrations remained stable and reached a plateau accounting for approximately $60 \%$ of the initial POC in both batches (Fig. 3a).

The degradation rate constant of PON was higher in the "P-replete" batch than in the "P-stress" batch $\left(0.27 \pm 0.02 \mathrm{~d}^{-1}\right.$ vs. $0.17 \pm 0.03 \mathrm{~d}^{-1}$; Table 3). Similar to POC, after 7-8 days of degradation, PON concentrations reached a plateau that accounted for approximately $40 \%$ of the initial PON in both batches (Fig. 3b). The $\mathrm{bSiO}_{2}$ in the "Preplete" and "P-stress" batches dissolved with the exponential decrease commonly 
observed in dissolution experiments and $\mathrm{bSiO}_{2}$ dissolution rate constants were calculated according to model 1 . An opposite trend was observed when compared to POC and PON degradation, with a faster $\mathrm{bSiO}_{2}$ dissolution in the "P-stress $T$. weissflogii" batches than in the "P-replete T. weissflogii" batches. Frustules from the "P-stress" T. weissflogii batch were dissolved with a rate constant of $0.05 \pm 0.02 \mathrm{~d}^{-1}$, about twice the rate calculated in the "P-replete $T$. weissflogii" batch $\left(0.02 \pm 0.01 \mathrm{~d}^{-1}\right.$; Table 3). After 3 weeks of dissolution, about $38 \%$ of the $\mathrm{bSiO}_{2}$ has been dissolved in the "P-replete T. weissflogii" batch while $64 \%$ of the $\mathrm{bSiO}_{2}$ has been dissolved in the "P-stress T. weissflogii" batch.

\subsection{2. $\mathrm{PCHO}$}

In contrast to $\mathrm{POC}$ and $\mathrm{PON}$, and alike $\mathrm{bSiO}_{2}$, the degradation rate constant for the PCHO-C was higher in the "P-stress T. weissflogii" batch $\left(0.92 \pm 0.18 \mathrm{~d}^{-1}\right)$ than in the "P-replete $T$. weissflogii" batch $\left(0.15 \pm 0.08 \mathrm{~d}^{-1}\right)$, indicating a rapid degradation of carbohydrates from T. weissflogii grown under P-stress conditions (Fig. 4b; Table 3). At the end of 20 days of degradation, approximately $60 \%$ of the initial PCHO-C pool remained in the "P-replete T. weissflogii" batch, whereas $\mathrm{PCHO}-\mathrm{C}$ represented $30 \%$ of the initial PCHO-C pool in the "P-stress T. weissflogil" batch.

The degradation rate constants showed significant differences between the monosaccharides in these two experiments. In general, higher values were recorded in the "P-stress" experiment than in the "P-replete" experiment, which agrees with the pattern that was observed for the total PCHO pool (Table 3). Xylose, followed by glucose and galactose, were the monosaccharides that exhibited the highest degradation rates in the "P-stress" experiment $\left(k_{l}=0.80-1.52 \mathrm{~d}^{-1}\right)$, whereas galacturonic acid, 
ribose, and galactose rates reached the highest values in the "P-replete" experiment $\left(k_{l}=\right.$ 0.17-0.49 $\mathrm{d}^{-1}$; Fig. 5). The degradation rate constants of the other monosaccharides showed little (e.g., glucosamine and rhamnose) to no degradation (e.g., arabinose) in both experiments (Table 4). The non-degradable pool (i.e., $\mathrm{C}_{2}$ ) comprised $29-83 \%$ and 17-61\% of the "P-replete" and "P-stress" T. weissflogii batches, respectively (Fig. 5; Table 4).

\section{Discussion}

\subsection{Impact of P-stress on the initial biochemical composition of T. weissflogii}

Previous investigations that assessed the impact of P-stress on diatoms observed increases in their absolute carbon ( $\mathrm{pmol} \mathrm{C} \mathrm{Cell}^{-1}$ ), probably attributed to the biosynthesis of sulfolipids and betaine lipids (Obata et al., 2013; Brembu et al., 2017), and occasionally in their nitrogen (pmol N cell ${ }^{-1}$ ) content (Lynn et al., 2000; Chauton et al., 2013). The results of this study agree with the general increase of $\mathrm{C}$ and $\mathrm{N}$ content and confirm that a P-stress may strongly affect the carbon and nitrogen contents per cell of T. weissflogii (Table 1). Our results also showed a decrease in the $\mathrm{bSiO}_{2}$ content due to P-stress, which was also reflected in the $\mathrm{Si} / \mathrm{C}$ and $\mathrm{Si} / \mathrm{N}$ ratios (Table 1). It is generally admitted that a decrease in the growth rate due to nutrient stress other than Si-limitation leads to an increase of the cellular $\mathrm{bSiO}_{2}$ content (Martin-Jézéquel et al. 2000, Claquin et al. 2002). However, low Si quotas have sometimes been measured for nutrientstressed diatoms in in situ or laboratory studies, which may partially be explained by the simultaneous decrease of the T. weissflogii cellular volume (Bucciarelli et al. 2010; Lasbleiz et al. 2014; Suroy et al., 2015; Boutorh et al., 2016). These results are contrary to what has been measured for T. pseudonana (Claquin et al., 2002) but agree well with 
what has been observed for T. weissflogii (De La Rocha et al., 2010), emphasizing the idea that diatoms of the same genus may have a different physiological response to environmental stress.

The elemental ratios of the "P-replete" cells were similar to those reported in the literature (Redfield et al., 1963; Brzezinski, 1985; Sarthou et al., 2005), with C/N of 6.7, $\mathrm{Si} / \mathrm{N}$ of 1.1 , and $\mathrm{Si} / \mathrm{C}$ of 0.17 . P-stress induced a decrease of the $\mathrm{Si} / \mathrm{N}$ and $\mathrm{Si} / \mathrm{C}$ ratios from 1.1 to 0.46 , and from 0.17 to 0.08 , respectively, which is similar to what has been observed for N- and Si- limitations stress (Suroy et al., 2015). In our study, P-stress induced a slight decrease in the $\mathrm{C} / \mathrm{N}$ ratio from 6.7 to 6 (Table 1). Contrarily, most previous studies observed an increase in $\mathrm{C} / \mathrm{N}$ ratios under nutrient stress especially for N- and Si- stress (Suroy et al., 2015; De La Rocha et al., 2010). However, a recent study by Clark et al. (2014) illustrated very well the strong variability of $\mathrm{C} / \mathrm{N}$ ratios under $\mathrm{P}$ limitation stress for $T$. weissflogii. The variability of this ratio may be explained by an irregular excretion of polysaccharides to regulate the $\mathrm{C} / \mathrm{N}$ ratios of diatom cells (Suroy et al. 2015).

The PCHO concentrations in the "P-replete T. weissflogil" batch were lower than those found in the "P-stress T. weissflogii" batch, accounting for $14 \%$ and $16 \%$ of POC, respectively (Table 2). The carbohydrate data presented here agree with those of previous investigations that assessed the impact of $\mathrm{P}$-stress in T. pseudonana after analyzing its carbohydrate and lipid components (Harrison et al., 1990b; Urbani et al., 2005). Moreover, our results are consistent with the potential regulation of glycolysis that has been observed in similar diatoms (e.g., T. pseudonana) that face strong phosphate limitation (Dyhrman et al., 2012). 
At the molecular level, the carbon allocation towards the carbohydrate component under "P-stress $T$. weissflogii" conditions was mainly reflected by the largest proportions of glucose, galactose, and xylose (Table 2). Galactose and xylose are generally found as parts of structural, extracellular heteropolysaccharides, whereas glucose is derived from both structural and storage ( $\beta-1,3$ glucan; e.g., chrysolaminarin) compounds in diatoms (Haug and Myklestad, 1976; Hicks et al., 1994; Chiovitti et al., 2003; Størseth et al., 2005). Although the carbohydrate analysis presented here does not allow for the differentiation of the origin of glucose (i.e., storage vs. structural monosaccharide), the high levels of glucose, galactose, and xylose most likely reflect the excretion and rapid degradation of structural polysaccharides under P-stress conditions (Magaletti et al., 2004; Ai et al., 2015). It is worth noting that high glucose and xylose levels have also been reported under "N-stress" conditions for T. weissflogii (Suroy et al., 2015). The most striking result of this study is the low relative abundance of ribose in the "P-stress" experiment (4.3\% of PCHO) compared to the "P-replete $T$. weissflogii" experiment (19.5\% of PCHO; Table 2), which further suggests the better physiological status of $T$. weissflogii cells, and the presence of ribose-containing molecules (e.g., DNA and ATP) under "P-replete T. weissflogii" conditions. This result is consistent with previous investigations that assessed N- and Si-stress in T. weissflogii cells and showed low ribose levels (Suroy et al., 2015).

4.2. Effect of $P$-stress on the degradation of $T$. weissflogii organic matter, $\mathrm{bSiO}_{2}$ dissolution, and PCHO T. weissflogii dynamics

The kinetic calculations of the POC and PON degradation of T. weissflogii grown under P-replete or P-stress conditions, suggest the presence of two pools of 
organic matter: one that exhibited high degradation during the first $7-8$ days, and a second, less degradable pool that showed no degradation $\left(k_{2}=0\right.$ for model $\left.2 \mathrm{~b}\right)$ and left behind a so-called "recalcitrant" component (Table 3; Fig. 3). Such a feature has already been well-documented for different types of organic matter, including fresh phytoplanktonic cultures (Westrich and Benner, 1984; Harvey et al., 1995; Sempéré et al., 2000; Moriceau et al., 2009). In an earlier study on T. weissflogii degradation under Si- and N-stress conditions (Suroy et al., 2015), it was observed that the second-order degradation rate constant (i.e., $\left.k_{2}\right)$ was almost equal to zero $\left(k_{1}>>k_{2} \approx 0\right)$, which agrees with the data presented in Table 3. Moreover, and similarly to N-stressed T. weissflogii (Suroy et al., 2015), the degradation rate constants for POC and PON were higher for the T. weissflogii grown under "P-replete" conditions than those grown under "P-stress" conditions, suggesting that nutrient growth conditions (herein the availability of $\mathrm{P}$ ) also impact the degradation of photosynthesized organic matter. Degradation rates of POC and PON also indicated that $\mathrm{N}$-containing organic molecules disappear more rapidly when they are produced by $T$. weissflogii cells grown under the presence of $\mathrm{P}$ (Table 3 ). Moreover, while the pool of degradable material was more rapidly utilized in the "Preplete $T$. weissflogii" batch than in the "P-stress $T$. weissflogii" batch, the contribution of the non-degradable pool to the global PON and POC was similar in both batches (Fig. 3). Overall, the results showed that the diatom-organic matter resulting from a Pstress environment might be less labile than the diatom-organic matter produced in nutrient-replete surface layers. Therefore, if $\mathrm{P}$ limits diatom growth, diatom-organic matter is less susceptible to degradation despite the fact that similar amount of total PON and POC may reach the mesopelagic/bathypelagic layers after 21 days of degradation (Fig. 3). 
In contrast to with POC and PON, which degraded less rapidly under "P-stress" conditions, $\mathrm{bSiO}_{2}$ showed a higher dissolution in the "P-stress" experiment (Table 3). Indeed, we measured a dissolution rate constant twice faster in the "P-stress $T$. weissflogii" batch than in the "P-replete T. weissflogii" batch. The FTIR spectra of the frustule cleaned from the organic coating showed that more organic matter was associated to the "P-replete" than to the "P-stress" frustule (Soler, 2010; Fig. S2). This result strongly suggests that when silica frustules are closely associated with a high amount of organic matter, $\mathrm{bSiO}_{2}$ dissolution rate (as shown by FTIR spectra) is slowed down which agrees with a similar study performed in our lab on Pseudonitzschia delicatissima (Boutorh, 2014). Indeed, the $\mathrm{bSiO}_{2}$ dissolution involves a reaction between the silanol group of the frustules and a water molecule. Therefore, a high amount of organic matter associated to the frustules may reduce the access to the reactive silanol groups, which further decreases the $\mathrm{bSiO}_{2}$ dissolution rate (Loucaides et al. 2010). Overall, these results suggest that $\mathrm{bSiO}_{2}$ produced under "P-stress" contains less organic matter and is less resistant to dissolution. The ballast effect of the $\mathrm{bSiO}_{2}$ may, therefore be decreased initially because of the low $\mathrm{Si} / \mathrm{C}$ ratios (Armstrong et al., 2002; Armstrong et al., 2009; Tréguer et al., 2018; Table 1) resulted from "P-stress" and secondly because $\mathrm{bSiO}_{2}$ dissolves more rapidly in "P-stress" than in "P-replete" $T$. weissflogii batches.

The rapid degradation of $\mathrm{PCHO}$ observed for the "P-stress T. weissflogii" experiment (Table 3) implies an allocation of excess carbon toward highly energetic molecules (i.e., carbohydrates), which can easily be assimilated after enzymatic hydrolysis (Fig. 4b). At the molecular level, this finding was mainly reflected in the contents of galactose, glucose, mannose, and xylose, which were among the most 
abundant compounds (Table 2). The elevated concentrations of galactose, accompanied by xylose and glucose, and mannose, in the "P-stress $T$. weissflogii" batch when compared to the "P-replete $T$. weissflogii" batch most likely indicate the biosynthesis and/or excretion of structural polysaccharides during diatom growth under "P-stress $T$. weissflogii" conditions. The above monosaccharides are known to constitute the building blocks of structural polysaccharides (i.e., heteropolysaccharides) and are rapidly degraded by prokaryotes (Table 2; Fig. 5). Alternatively, these structural polysaccharides may contribute to building up the extracellular pool of EPS (Myklestad, 1977; Urbani et al., 2005; Passow, 2002), rich in glucose (Waite et al. 1995), and are the precursors of transparent exopolymer particles (TEP). In turn, TEP may trigger the formation of large, fast-sinking aggregates that are known to increase $\mathrm{C}$ export (Passow, 2002; Moriceau et al., 2007; Seebah et al., 2014; Chen et al., 2015).

In contrast to the above monosaccharides, ribose exhibited higher degradation rates in the "P-replete $T$. weissflogii" degradation experiment than in the "P-stress $T$. weissflogii" degradation experiment. This result, in conjunction with the elevated concentrations of ribose in the "P-replete" experiment, points toward a high lability of T. weissflogii organic material (note that ribose may be considered as a good proxy of fresh organic material as it is mostly found in metabolically active organisms), and a subsequent better degradation "behavior" of prokaryotes when T. weissflogii cells are grown under the presence of $\mathrm{P}$ (Table 2). Moreover, the exhaustion of ribose during the growth of $T$. weissflogii in the absence of P resulted in little bioavailability of these energy-rich ATP-containing molecules during degradation, as suggested by their low degradation rates (Table 4). A similar observation was made for ribose under $\mathrm{N}$ - and Sistress conditions during the degradation of T. weissflogii (Suroy et al., 2015). 


\section{Conclusions}

This study showed that "P-stress $T$. weissflogii" conditions induced an increase in the contents of POC and PON in the T. weissflogii cells, with a concomitant decrease in their silicon content $\left(\mathrm{bSiO}_{2}\right)$. The initial $T$. weissflogii chemical composition in the " $\mathrm{P}$ stress" cells was characterized by high abundances of glucose (19\% of PCHO), galactose (23\%), and xylose (21\%) compared to the "P-replete" cells, which were dominated by ribose (20\% of PCHO). These results clearly suggest that "P-stress $T$. weissflogii" conditions cause changes in carbon allocation toward the carbohydrate component (i.e., synthesis of storage/structural polysaccharides). The modeling of $T$. weissflogii degradation in terms of bulk organic matter ( $\mathrm{POC}, \mathrm{PON}$, and $\mathrm{bSiO}_{2}$ ) indicated that the degradation rate constants for POC and PON were always higher in the "P-replete $T$. weissflogii" experiment $\left(k_{1}=0.27-0.40 \mathrm{~d}^{-1}\right)$ than in the "P-stress $T$. weissflogii" experiment $\left(k_{1}=0.19-0.17 \mathrm{~d}^{-1}\right)$. Contrarily, $\mathrm{bSiO}_{2}$ formed under "P-stress T. weissflogil" conditions dissolved more rapidly than $\mathrm{bSiO}_{2}$ produced under "P-replete T. weissflogii" conditions as the latter contains more organic matter strongly associated to the frustule. Overall, our study illustrates the critical role that $\mathrm{P}$ plays in the degradation of diatom organic matter and its impact on silica frustule dissolution and carbohydrate decomposition. Although further investigations are needed with different types of diatoms in order to make any generalizations, it appears that P-limitation on diatom growth may have important implications to the degradation of diatom-derived organic matter and, consequently, to the associated export fluxes to the ocean interior.

\section{Acknowledgments}


We thank D. Delmas for prokaryote counting during the degradation experiment and C. Labry for seawater sampling at the Brest Somlit station. The authors also acknowledge C. Soler for laboratory and field assistance and A. Masson for POC/PON measurements. This manuscript benefited from the constructive comments of two anonymous reviewers, who are also acknowledged. This study was supported by the UTIL (LEFE/CYBER, CNRS/INSU) and MANDARINE (Région Provence Alpes Côte d'Azur) projects. M. Suroy acknowledges the Aix-Marseille University for his Ph.D. scholarship.

\section{References}

Agusti, S., Gonzalez-Gordillo, J.I., Vaqué, D., Estrada, M., Cerezo, M.I., Salazar, G., Gasol, J.M., Duarte, C.M., 2015. Ubiquitous healthy diatoms in the deep sea confirm deep carbon injection by the biological pump. Nature Commun. 6:7608. DOI: $10.1038 /$ ncomms 8608.

Ai, X.-X., Liang, J.-R., Gao, Y.-H., Lo, S.C.-L., Lee, F.W.-F., Chen, C.-P., Luo, C.-S., Du, C., 2015. MALDI-TOF MS analysis of the extracellular polysaccharides released by the diatom Thalassiosira pseudonana under various nutrient conditions. J. Appl. Phycol. 27, 673-684.

Armstrong, R.A., Lee, C., Hedges, J.I., Honjo, S., Wakeham S.G., 2002. A new, mechanistic model for organic carbon fluxes in the ocean based on the quantitative association of POC with ballast minerals. Deep-Sea Res II 49, 219-236.

Armstrong, R.A., Peterson, M.L., Lee, C., Wakeham, S.G., 2009. Settling velocity spectra and the ballast ratio hypothesis. Deep Sea Res. Part II 56: 1470-1478. 
Beardall, J., Berman, T., Heraud, P., Kadiri, M. O., Light, B. R., Patterson, G., et al. 2001. A comparison of methods for detection of phosphate limitation in microalagae. Aquat. Sci. 63, 107-121.

Berg, J.M., Tymoczko, J.L., Stryer, L., 2002. Biochemistry. $5^{\text {th }}$ edition, New York.

Brembu, T., Muhlrorth, A., Alipanah, L., Bones, A. M., 2017. The effects of phosphorus limitation on carbon metabolism in diatoms. Phil. Trans. R. Soc. B 372: 20160406.http://dx.doi.org/10.1098/rstb.2016.0406

Boop, L., Aumont, O., Cadule, P., et al. 2005. Response of diatoms distribution to global warming and potential implications: A global model study. Geophys. Res. Lett. 32. https://doi. 10.1029/2005GL023653.

Boutorh, J., 2014. Impact des conditions nutritionnelles sur la dissolution de la silice biogénique des diatomées à travers l'étude de la variabilité de la structure biphasique du frustule. Ph.D. dissertation, Université de Bretagne Occidentale, France, pp 14.

Boutorh, J., Moriceau, B., Gallinari, M., Ragueneau, O., Bucciarelli, E., 2016. Effect of trace metal-limited growth on the postmortem dissolution of the marine diatom Pseudo-nitzschia delicatissima. Global Biochem. Cy. 30, 57-69. DOI: $10.1002 / 2015 \mathrm{~GB} 005088$

Brzezinski, M.A., 1985. The Si:C:N ratio of marine diatoms : interspecific variability and the effet of some environmental variables. J. Phycol. 21, 347-57.

Bucciarelli, E., Pondaven, P., Sarthou, G., 2010. "Effects of an iron-light co-limitation on the elemental composition ( $\mathrm{Si}, \mathrm{C}, \mathrm{N}$ ) of the marine diatoms Thalassiosira oceanica and Ditylum brightwellii." Biogeosciences 7, 657-669. 
Chauton, M.S., Olsen, Y., Vadstein, O., 2013. Biomass production from the microalga Phaeodactylum tricornutum: Nutrient stress and chemical composition in exponential fed-batch cultures. Biomass and bioenergy 58, 87-94.

Chen, J., Thornton, D.C.O., 2015. Transparent exopolymer particle production and aggregation by a marine planktonic diatom (Thalassiosira weissflogii) at different growth rates. J. Phycol. 51, 381-393.

Chiovitti, A., Higgins, M.J., Harper, R.E., Wetherbee, R., 2003. The complex polysaccharides of the raphid diatom Pinnularia viridis (Bacillariophyceae). J. Phycol. 39, 543-554.

Claquin, P., Martin-Jézéquel, V., Kromkamp, J.C., Veldhuis, M. J. W., Kraay, G. W., 2002. Uncoupling of silicon compared to carbon and nitrogen metabolism, and role of the cell cycle, in continuous cultures of Thalassiosira pseudonana (bacillariophyceae) under light, nitrogen and phosphorus control. J. Phycol. 38, 922-930.

Clark, D. R., Flynn, K. J., Fabian, H., 2014. Variation in elemental stoichiometry of the marine diatom Thalassiosira weissflogii (Bacillariophyceae) in response to combined nutrient stress and changes in carbonate chemistry. J. Phycol. 50, 640651. doi:10.1111/jpy.12208.

De La Rocha, C.L., Terbrüggen, A., Völker, C., Hohn, S., 2010. Response to and recovery from nitrogen and silicon starvation in Thalassiosira weissflogii: growth rates, nutrient uptake and C, Si and N content per cell. Mar. Ecol. Prog. Ser. 412, $57-68$. 
Diekmann, A.B.S., Peck, M.A., Holste, L., St John, M.A., Campbell, R.W., 2009. Variation in diatom biochemical composition during a simulated bloom and its effect on copepod production. J. Plankton Res. 31, 1391-1405.

Downing, J.A., 1997. Marine nitrogen: Phosphorus stoichiometry and the global N:P cycle. Biogeochemistry 37, 237-252.

Duhamel, S., Moutin, T., Van Wambeke, F., Van Mooy, B., Raimbault, P., Chaustre, H., 2007. Growth and specific P-uptake rates of bacterial and phytoplanktonic communities in the Southeast Pacific (BIOSOPE cruise). Biogeosciences 4, 941956.

Dyhrman, S.T., Jenkins, B.D., Rynearson, T.A., Saito, M.A., Mercier, M.L., Alexander, H., Whitney, L.P., Drzewianowski, A., Bulygin, V.V., Bertrand, E.M., Wu, Z., Benitez-Nelson, C., Heithoff, A., 2012. The transcriptome and proteome of the diatom Thalassiosira pseudonana reveal a diverse phosphorus stress response. PloS one, 7, e33768. htpps://doi.org/10.1371/journal.pone.0033768.

Engel, A., Abramson, L., Szlosek, J., Liu, Z., Stewart, G., Hirschberg, D., Lee, C., 2009. Investigating the effect of ballasting by $\mathrm{CaCO}_{3}$ in Emiliania huxleyi, II: Decomposition of particulate organic matter. Deep-Sea Res. II 56, 1408-1419. DOI:10.1016/j.dsr2.2008.11.028

Gärdes, A., Iversen, M. H., Grossart, H. P., Passow, U., Ullrich, M. S., 2010. Diatomassociated bacteria are required for aggregation of Thalassiosira weissflogii. ISME J. 5, 436-445. 
Godwin, C.M., Cotner, J.B., 2015 Aquatic heterotrophic bacteria have highly flexible phosphorus content and biomass stoichiometry. ISME J. https://doi:10.1038/ismej.2015.34

Gordon, L.I., Jennings, J.C., Ross, A.A., Krest, J.M., 1993. A suggested protocol for continuous flow automated analysis of seawater nutrients. In Group, C. o. [Ed.] OSU, College of Oc. Descriptive. Chem. Oc. Grp. Tech. Rpt. OSU College of Oceanography Descriptive, Corvallis, pp. 1-55.

Goutx, M., Wakeham, S.G., Lee, C., Duflos, M., Guigue, C., Liu, Z., Moriceau, B., Sempéré, R., Tedetti, M., Xue, J., 2007. Composition and degradation of marine particles with different settling velocities in the northwestern Mediterranean Sea. Limnol. Oceanogr. 52, 1645-64.

Grattepanche, J-D., Vincent, D., Breton, E., Christaki, U., 2011. Microzooplankton herbivory during the diatom-Phaeocystis spring succession in the eastern English Channel. J. Exp. Mar. Biol. Ecol. 404, 87-97.

Greenwood, J.E., Truesdale, V.W., Rendell, A.R., 2001. Biogenic silica dissolution in seawater - in vitro chemical kinetics. Prog. Oceanogr. 48, 1-23.

Gruber, N., Galloway, J.N., 2008. An Eath-system perspective of the global nitrogen cycle. Nature, 451, 293-96. https://doi:10.1038/nature06592.

Guillard, R.R.L., Ryther, J.H., 1962. Studies of marine planktonic diatoms. I. Cyclotella nana hustedt and Detonela confervacea (cleve) gran. Can. J. Microbiol. 8, 229239.

Guillard, R.R.L., 2005. Purification methods for microalgae, in: Andersen, R.A (Ed.) Algal Culturing Techniques. Elsevier Academic Press, Burlington, MA, USA, pp. 117-132. 
Harrison, P.J., Hu, M.H., Yang, Y.P., Lu, X., 1990a. Phosphate limitation in estuarine and coastal waters of China. J. Exp. Mar. Biol. Ecol. 140, 79-87. DOI: 10.1016/0022-0981(90)90083-O.

Harrison, P.J., Thompson, P.A., Calderwood, G.S., 1990b. Effects of nutrient and light limitation on the biochemical composition of phytoplankton. J. Appl. Phycol. 2, $45-56$.

Harvey, H.R., Tuttle, J.H., Bell, J.T., 1995. Kinetics of phytoplankton decay during simulated sedimentation: Changes in biochemical composition and microbial activity under oxic and anoxic conditions. Geochim. Cosmochim. Acta 59, 336777.

Harvey, H.R., Macko, S.A., 1997. Kinetics of phytoplanktondecay during simulated sedimentation: changes in lipids under oxic and anoxic conditions. Org. Geochem. $129-140$.

Haug, A., Myklestad, S.M., 1976. Polysaccharides of marine diatoms with special reference to Chaetoceros species. Mar. Biol. 34, 217-22.

Hicks, R.A., Owen, C.J., Aas, P., 1994. Deposition, resuspension, and decomposition of particulate organic matter in sediments of lake Itasca, Minnesota, USA. Hydrobiologia 284,79-91.

Jackson, G.A., Williams, P.M., 1985. Importance of dissolved organic nitrogen and phosphorus to biological nutrient cycling. Deep-Sea Res 32, 223-35.

Kamatani, A., Riley, J.P., 1979. Rate of dissolution of diatom silica walls in seawater. Mar. Biol. 55, 29-35.

Kamatani, A., Riley, J.P., Skirrow, G., 1980. The dissolution of opaline silica of of diatom tests in seawater. J. Oceanogr. Soc. Jpn 36, 201-8. 
Kamatani, A., 1982. Dissolution rates of silica from diatoms decomposing at various temperature. Mar. Biol. 68, 91-96.

Karl, D.M., Björkman, K,M., 2015. Dynamics of dissolved organic phosphorus, in: Hansell, D.A., Carlson, C.A., (Eds.) Biogeochemistry of marine dissolved organic matter. Academic Press, New York. pp. 233-318.

Lasbleiz, M., Leblanc, K., Blain, S., Ras, J., Cornet-Barthaux, V., Hélias Nunige, S., Quéguiner, B., 2014. Pigments, elemental composition (C, N, P, Si) and stoichiometry of particulate matter, in the naturally iron fertilized region of Kerguelen in the Southern Ocean, Biogeosciences 11, 5931-5955, doi.org/10.5194/bg-11-5931-2014.

Lehninger, A.L., Nelson, D.L., Cox, M.M., 1993. Principles of Biochemistry, 2nd ed. Worth Publishers, New York.

Liu, S., Guo, Z.L., Li, T., Huang, H., Lin, S.J., 2011. Photosynthetic efficiency, cell volume, and elemental stoichiometric ratios in Thalassirosira weissflogii under phosphorus limitation. Chinese J. Oceanol. Limnol. 29, 1048-56.

Loucaides, S., Behrends, T., Van Cappellen, P., 2010. Reactivity of biogenic silica: surface vs bulk charge density. Geochim. Cosmochim. Acta 74, 517-530.

Lynn, S.G., Kilham, S.S., Kreeger, D.A., Interlandi, S.J., 2000. Effect of nutrient availability on the biochemical and elemental stoichiometry in the freshwater diatom Stephanodiscus minutulus (Bacillariophyceae). J. Phycol. 36, 510-22.

Magaletti, E., Urbani, R., Sist, P., Ferrari, C.R., Cicero, A.M., 2004. Abundance and chemical characterization of extracellular carbohydrates released by the marine diatom Cylindrotheca fusiformis under N- and P- limitation. Eur. J. Phycol. 39, $133-42$. 
Marie, D., Partensky, F., Jacquet, S., Vaulot, D., 1997. Enumeration and cell cycle analysis of natural populations of marine picoplankton by flow cytometry using the nucleic acid stain SYBR Green I. Appl. Environ. Microbiol. 63, 186-93.

Marie, D., Partensky, F., 2006. Analyse des micro-organismes marin. In La cytométrie en flux, Lavoisier, Edition Tec and Doc; Ronot, R., Grunwald, D., Mayol , J.-F., Boutonnat, J., coordonateurs, p. 210-33.

Moore, C.M., Mills, M., Langlois, R., Milne, A., Achterberg, E.P., La Roche, J., Geider, R.J., 2008. Relative influence of nitrogen and phosphorus availability on phytoplankton physiology and productivity in the oligotrophic sub-tropical North Atlantic Ocean. Limnol. Oceanogr. 53, 291-305.

Moore, C.M., Mills, M.M., Arrigo, K.R., Berman-Frank, I., Bopp, L., Boyd, P.W., Galbraith, E.D., Geider, R.J., Guieu, C., Jaccard, S.L., Jickells, T.D., La Roche, J., Lenton, T.M., Mahowald, N.M., Maranon, E., Marinov, I., Moore, J.K., Nakatsuka, T., Oschlies, A., Saito, M.A., Thingstad, T.F., Tsuda, A., Ulloa O., 2013. Processes and patterns of oceanic nutrient limitation. Nat. Geosci. 6: 701710. doi: 10.1038/NGEO1765.

Moriceau, B., Gallinari, M., Soetaert, K., Ragueneau, O., 2007. Importance of particle formation to reconstructed water column biogenic silica fluxes. Glob. Biogeochem. Cycles 21, GB3012. doi:10.1029/2006GB002814.

Moriceau, B., Goutx, M., Guigue, C., Lee, C., Armstrong, R.A., Duflos, M., Tamburini, C., Charrière, B., Ragueneau, O., 2009. Si-C interactions during degradation of the diatom Skeletonema marinoi. Deep-Sea Res. II 56,1381-95.

Myklestad, S.M., 1977. Production of carbohydrates by marine planktonic diatoms. 2. Influence of N/P ratio in growth medium on assimilation ratio, growth rate, and 
production of cellular and extracellular carbohydrates by Chaetocearos affinis var Willei (Gran) Hustedt and Skele. J. Exp. Mar. Biol. Ecol. 29:161-79.

Némery, J., Garnier, J., 2016. The fate of phosphorus. Nature Geosci. 9, 343-344.

Nieuwenhuize, J., Maas, Y.E.M., Middelburg, J.J., 1994. Rapid analysis of organic carbon and nitrogen in particulate materials. Mar. Chem. 45, 217-24.

Obata, T., Fernie, A.I., Nunes-Nesi, A., 2013. The Central Carbon and Energy Metabolism of Marine Diatoms. Metabolites, 3, 325-346; doi:10.3390/metabo3020325.

Palmucci, M., Ratti, S., Giordano, M., 2011. Ecological and evolutionary implications of carbon allocation in marine phytoplankton as a function of nitrogen availability: a fourier transform infrared spectroscopy approach. J. Phycol. 47, 313-323.

Panagiotopoulos, C., Sempéré, R., Obernosterer, I., Striby, L., Goutx, M., Van Wambeke, F., Gautier, S., Lafont, R., 2002. Bacterial degradation of large particles in the southern Indian Ocean using in vitro incubation experiments. Org. Geochem. $33,985-1000$.

Panagiotopoulos, C., Sempéré, R., 2007. Sugar dynamics in large particles during in vitro incubation experiments. Mar. Ecol. Prog. Ser. 330, 67-74.

Panagiotopoulos, C., Sempéré, R., Para, J., Raimbault, P., Rabouille, C., Charrière, B., 2012. The composition and flux of particulate and dissolved carbohydrates from the Rhone River into the Mediterranean Sea. Biogeosciences 9, 1827-1844.

Panagiotopoulos, C., Wurl, O., 2009. Spectrophotometric and chromatographic analysis of carbohydrates in marine samples, in: Wurl, O., (Ed.) Practical Guidelines for the Analysis of Seawater. Taylor and Francis, Boca Raton, FL, pp. 49-65. 
Passow, U., 2002. Production of transparent exopolymer particles (TEP) by phyto- and bacterioplankton, Mar. Ecol. Prog. Ser. 236, 1-12.

Piontek, J., Handel, N., Langer, G., Wohlers, J., Riebesell, U., Engel, A., 2009. Effects of rising temperature on the formation and microbial degradation of marine diatom aggregates. Aquat. Microb. Ecol. 54, 305-318. DOI: 10.3354/ame01273.

Paytan, A., McLaughlin, K., 2007. The oceanic phosphorus cycle. Chem. Rev. 107, $563-76$.

Ragueneau, O., Treguer, P., 1994. Determination of biogenic silica in coastal waters:Applicability and limits of alkaline digestion method. Mar. Chem. 45, 4351.

Redfield, A.C., Ketchum, B.H., Richards, F.A., 1963. The influence of organisms on the composition of sea water, in: Hill, M.N., (Ed.) The sea: ideas and observations on progress in the study of the seas. Interscience, New York, pp 26-77.

Ryther, J.H., Dunstan, W.H., 1971. Nitrogen, phosphorus and eutrophication in the coastal marine environment. Science 171:1008-13.

Sarthou, G., Timmermans, K.R., Blain, S., Tréguer, P., 2005. Growth physiology and fate of diatoms in the ocean: a review. J. Sea Res. 53, 25-42. DOI: 10.1016/j.seares.2004.01.007.

Schreiber, U., Schliwa, U., Bilger, W., 1986. Continuous recording of photochemica and nonphotochemical chlorophyll fluorescence quenching with a new type of modulation fluorometer. Photosynth. Res. 10, 51-62.

Sebastian, M., Smith, A.F., Gonzalez, J.M., Fredricks, H.F., et al. 2016. Lipid remodeling is a widespread strategy in marine heterotrophic bacteria upon 
phosphorus deficiency. ISME journal. 10, 968-78. https://doi:

10.1038/ismej.2015.172

Seebah, S., Fairfield, C., Ullrich, M.S., Passow, U., 2014. Aggregation and Sedimentation of Thalassiosira weissflogii (diatom) in a Warmer and More Acidified Future Ocean. Plos One 9. https:// doi: 10.1371/journal.pone.0112379.

Sempéré, R., Yoro, S-C., Van Wambeke, F., Charrière, B., 2000. Microbial decomposition of large organic particles in the northwestern Mediterranean Sea: an experimental approach. Mar. Ecol. Prog. Ser. 198, 61-72.

Shifrin, N.S., Chisholm, S.W., 1981. Phytoplankton lipids interspecific differences and effects of nitrate, silicate and light-dark cycles. J. Phycol. 17, 374-84.

Smetacek, V., 1985. Role of sinking in diatom life-history cycles: ecological, evolutionary and geological significance. Mar. Biol. 84, 239-251.

Soler, C., 2010. Impact des conditions de croissance sur le métabolisme et les interactions Si-OC des diatomées-conséquences sur la vitesse de reminéralisation de la silice biogène et de la matière organique. Ph.D. dissertation, Université de Bretagne Occidentale, France, pp. 207.

Størseth, T.R., Hansen, K., Reitan, K.I., Skjermo, J., 2005. Structural characterization of $\beta$-D-( $1 \rightarrow 3)$-glucans from different growth phases of the marine diatoms Chaetoceros mülleri and Thalassiosira weissflogii. Carbohyd. Res. 340:1159-64. Sun, M.Y., Lee, C., Aller, R.C., 1993. Anoxic and oxic degradation of C-14-labeled chloropigments and a C-14-labeled diatom in long-island sound sediments. Limnol. Ocenogr. 38, 1438-1451. 
Suroy, M., Panagiotopoulos, C., Boutorh, J., Goutx, M., Moriceau, B., 2015.

Degradation of diatom carbohydrates: A case study with $\mathrm{N}-$ and $\mathrm{Si}-$ stressed Thalassiosira weissflogii. J. Exp. Mar. Biol. Ecol. 470, 1-11.

Tanaka, T., Thingstad, T.F., Christaki, U., Colombet, J., et al. 2011. Lack of Plimitation of phytoplankton and heterotrophic prokaryotes in surface waters of three anticyclonic eddies in the stratified Mediterranean Sea. Biogeosciences 8, 525-38. DOI: $10.5194 / \mathrm{bg}-8-525-2011$.

Thingstad, T.F., Krom, M.D., Mantoura, R.F.C., Flaten, G.A.F, Groom, S., et al. 2005. Nature of phosphorus limitation in the ultraoligotrophic eastern Mediterranean. Science 309:1068-71.

Tréguer, P., Bowler, C., Moriceau, B., Dutkiewicz, et al. 2018. Influence of diatom diversity on the ocean biological carbon pump. Nature Geoscience 1:27-37. DOI: 10.1038/s41561-017-0028-x.

Trommer, G., Leynaert, A., Klein, C., Naegelen, A., Beker, B., 2013. Phytoplankton phosphorus limitation in a North Atlantic coastal ecosystem not predicted by nutrient load. J. Plankton Res. 35:1207-1219. doi:10.1093/plankt/fbt070.

Troussellier, M., Courties, C., Vaquer, A., 1993. Recent applications of flow cytometry in aquatic microbial ecology. Biol. Cell 78, 111-21.

Urbani, R., Magaletti, E., Sist, P., Cicero, A.M., 2005. Extracellular carbohydrates released by the marine diatoms Cylindrotheca closterium, Thalassiosira pseudonana and Skeletonema costatum: effect of P-depletion and growth status. Sci. Total Env. 353, 300-6. 
Van Mooy, B.A.S., Fredricks, H.F., Pedler, B.E., Dyhrman, S.T., et al (2009) Phytoplankton in the ocean use non-phosphorus lipids in response to phosphorus scarcity. Nature 458: 69-72.

Vitousek, P.M., Howarth, R.W., 1991. Nitrogen limitation on land and in the sea: How can it occur? Biogeochemistry 13, 87-115.

Waite, A.M., Bienfang, P., Harrison, P.J., 1992. Spring bloom sedimentation in a subarctic ecosystem.1. Nutrient sensitivity. Mar. Biol. 114, 119-29.

Westrich, J., Berner, R., 1984. The role of sedimentary organic matter in bacterial sulphate reduction: the G model tested. Limnol. Oceanogr. 29, 236-49.

Wetz, M.S., Hales, B., Wheeler, P.A., 2008. Degradation of phytoplankton-derived organic matter: implications for carbon and nitrogen biogeochemistry in coastal ecosystems. Estuar. Coast. Shelf Sci. 77: 422-432. DOI:

10.1016/j.ecss.2007.10.002.

Wu, J., Sunda, W., Boyle, E.A., Karl, D.M., 2000. Phosphate depletion in the western North Atlantic Ocean. Science 289, 759-62.

ZoBell, C.E., 1941. Studies on marine bacteria. I. The cultural requirement of heterotrophic aerobes. J. Mar. Res. 4, 42-75.

Zohary, T., Herut, B., Krom, M.D., Mantoura, R.F., et al 2005. P-limited bacteria but N and $\mathrm{P}$ co-limited phytoplankton in the Eastern Mediterranean - a microcosm experiment. Deep Sea Res. II 52, 3011-2. 


\section{Table Captions:}

Table 1. Initial parameters measured in each batch at the beginning $\left(\mathrm{T}_{0}\right)$ of the experiment. The previous assumption also considers that there is little variability in the POC, $\mathrm{PON}$, and $\mathrm{bSiO}_{2}$ concentrations between day 0 and day 1 of the experiment. Thus, the ratio of these parameters to the diatom cell does not change drastically between day 0 and day 1.

Table 2. Elemental carbohydrate compositions (as percentages of total sugar, mol\%) and the total $\mathrm{PCHO}-\mathrm{C}$ concentrations $(\mu \mathrm{M})$ during the 21 days of degradation. The PCHO yields are given as a percentage of the total $\mathrm{PCHO}-\mathrm{C}$ relative to the POC. Abbreviations: Fuc. - Fucose; Rha. - Rhamnose; Ara. - Arabinose; GlcN. Glucosamine; Gal. - Galactose; Glc. - Glucose; Man. - Mannose; Xyl. - Xylose; Rib. Ribose; GalUA. - Galacturonic Acid. The number of replicates is given in the caption of Fig. 4.

Table 3. Estimated kinetic parameters for $\mathrm{POC}, \mathrm{PON}, \mathrm{bSiO}_{2}$ and $\mathrm{PCHO}$ during the degradation of $T$. weissflogii. The standard error (SE) is given for each estimate. Extremely significant estimates are underlined $(p<0.0001)$. Kinetic parameters $\left(k_{1}, \mathrm{C}_{2}\right)$ were calculated according to models 1 and 2 using equations (1) and (2b) (see statistical analysis and estimation of kinetic parameters section). $k_{1}$ and $\mathrm{C}_{2}$ units are given in $\mathrm{d}^{-1}$ and $\mu \mathrm{mol} / \mu \mathrm{mol}$, respectively.

Table 4. Estimated kinetic parameters for individual monosaccharides during the biotic degradation of $T$. weissflogii. The standard error (SE) is given for each estimate. 
Extremely significant estimates are underlined $(p<0.0001)$. Abbreviations are the same as in Tables 2 and 3. Kinetic parameters $\left(k_{l}\right.$ in $\mathrm{d}^{-1}$ and $\mathrm{C}_{2}$ in $\left.\mu \mathrm{mol} / \mu \mathrm{mol}\right)$ were calculated according to model 1 and/or 2 using equations (1) and/or (2b).

\section{Figure Captions:}

Figure 1. Schematic presentation of the experimental design of sampling, growth and prokaryotic degradation of $T$. weissflogii cells (Fig. adapted from Suroy et al 2015).

Figure 2. Evolution of prokaryotic concentrations over time in the "P-replete $T$. weissflogii" and "P-stress $T$. weissflogii" batches during the biodegradation experiments. The prokaryotic concentrations correspond only to the free prokaryotes that were measured in the batches. At each sampling point $n=2$.

Figure 3. Time course responses of the (A) POC and (B) PON relative concentrations of $T$. weissflogii in the "P-replete $T$. weissflogii" and "P-stress $T$. weissflogii" batches. The relative concentrations were calculated by dividing the concentration on day $\mathrm{t}$ by the concentration on days 0 and 2 for "P-stress $T$. weissflogii" and "P-replete $T$. weissflogii" batches, respectively, for both POC and PON. The kinetics were estimated using equation (2b) (section 2.6). Replicate subsamples $(n=3)$ for "P-replete" and "Pstress" batches were performed on days $2,6,9,12$, and 19, and were used to feed the degradation model (section 2.5). In the "P-stress" batch, only an $n=2$ was obtained at day 12 for both POC and PON. 
Figure 4. Time course responses of the relative concentrations of (A) $\mathrm{bSiO}_{2}$ and (B) PCHO in the "P-replete T. weissflogii" and "P-stress T. weissflogii" batches. The relative concentrations were calculated by dividing the concentration on day t by the concentration on days 0 and 2 for the "P-stress $T$. weissflogii" and "P-replete $T$. weissflogii" batches, respectively, for both $\mathrm{bSiO}_{2}$ and $\mathrm{PCHO}$. The kinetics were estimated using equations (1) and (2b). For $\mathrm{bSiO}_{2}$ degradation, replicate subsamples $(n$ =3) were performed on days 2, 6, 9, and 19; and 2, 6, 9, 12, and 19 for the "P-replete $T$. weissflogii" and "P-stress T. weissflogii" experiments, respectively. On day 12 , only an $n=2$ was obtained for the "P-replete $T$. weissflogii" experiment. For PCHO degradation, replicate subsamples $(n=3)$ were performed on days 6,12 , and 19 and 2 , 6, and 19 for the "P-replete T. weissflogii" and "P-stress T. weissflogii" experiments, respectively. On days 9 and 12, only an $n=2$ was obtained for the "P-stress $T$. weissflogii" experiment.

Figure 5. Time course responses of (A) galactose, (B) glucose, (C) xylose and (D) ribose in the "P-replete T. weissflogii" and "P-stress T. weissflogii" batches. The relative concentrations were calculated by dividing the concentration on day $\mathrm{t}$ by the concentrations on day 0 and 2 for the "P-stress" and "P-replete" batches, respectively, for individual monosaccharides. The kinetics were estimated using equations (1) and (2b). The degradation rates, including experimental points, are given in Table 5. 
Table 1.

\begin{tabular}{|c|c|c|c|c|c|c|}
\hline $\begin{array}{l}\text { Growth } \\
\text { conditions }\end{array}$ & $\begin{array}{c}\text { Batch } \\
\text { volume (L) }\end{array}$ & $\begin{array}{c}\text { [T. weissflogii } \\
\text { cells] } \\
\text { (cell L-1) }\end{array}$ & $\begin{array}{c}{[\mathrm{POC}] /[T \text {. }} \\
\text { weissflogii cell }] \\
\left(\mathrm{pmol} \mathrm{cell}^{-1}\right) \\
\end{array}$ & $\begin{array}{c}{[\mathrm{PON}] /[T \text {. }} \\
\text { weissflogii cell }] \\
\left(\mathrm{pmol} \mathrm{cell}^{-1}\right) \\
\end{array}$ & $\begin{array}{c}\text { [Prokaryotic } \\
\text { inoculum] } \\
\left(\text { cell L }{ }^{-1}\right) \\
\end{array}$ & $\begin{array}{c}{\left[\mathrm{bSiO}_{2}\right] /[\text { diatom cell }]} \\
\left(\mathrm{pmol} \mathrm{cell}^{-1}\right)\end{array}$ \\
\hline $\begin{array}{l}\text { P-replete } T . \\
\text { weissflogii } \\
\text { P-stress } T\end{array}$ & 12 & $6.60 \times 10^{7}$ & 12.0 & 1.8 & $7.02 \times 10^{10}$ & 2.0 \\
\hline weissflogii & 12 & $6.80 \times 10^{7}$ & 15.5 & 2.6 & $5.64 \times 10^{10}$ & 1.2 \\
\hline
\end{tabular}


Table 2.

\begin{tabular}{|c|c|c|c|c|c|c|c|c|c|c|c|c|c|}
\hline Experiment & Time (d) & Fuc. & Rha. & Ara. & GlcN. & Gal. & Glc. & Man. & Xyl. & Rib. & GalUA & $\mathrm{PCHO}-\mathrm{C}$ & $\mathrm{PCHO}-\mathrm{C} / \mathrm{POC}$ \\
\hline \multirow{17}{*}{$\begin{array}{c}\text { «P-replete } T \text {. } \\
\text { weissflogii } »\end{array}$} & 0 & 10.1 & 6.29 & 1.03 & 2.66 & 18.4 & 12.4 & 13.4 & 14.2 & 19.5 & 2.07 & 110 & 13.9 \\
\hline & 1 & 8.72 & 5.73 & 0.72 & 4.87 & 16.7 & 16.6 & 15.1 & 12.1 & 16.8 & 2.69 & 112 & 7.23 \\
\hline & 2 & 10.0 & 6.61 & 1.14 & 4.16 & 18.5 & 14.5 & 11.6 & 13.1 & 18.6 & 1.80 & 104 & 6.12 \\
\hline & 4 & 9.29 & 5.11 & 2.06 & 5.14 & 18.6 & 19.5 & 13.6 & 13.4 & 12.5 & 0.93 & 113 & 8.19 \\
\hline & 5 & 9.34 & 6.44 & 2.95 & 9.11 & 17.2 & 15.4 & 10.7 & 15.7 & 12.0 & 1.33 & 107 & 8.11 \\
\hline & 6 & 11.3 & 7.86 & 2.69 & 5.39 & 16.3 & 18.2 & 10.4 & 14.9 & 12.0 & 0.94 & 83.9 & 7.06 \\
\hline & 7 & 11.7 & 9.49 & 2.09 & 5.95 & 13.5 & 17.4 & 10.4 & 16.1 & 12.7 & 0.67 & 80.0 & 7.01 \\
\hline & 10 & 10.8 & 10.5 & 2.28 & 8.32 & 13.1 & 17.5 & 14.0 & 13.9 & 8.85 & 0.82 & 61.3 & 5.78 \\
\hline & 11 & 9.77 & 7.41 & 1.78 & 8.38 & 14.3 & 18.5 & 16.8 & 14.7 & 7.75 & 0.58 & 83.6 & 7.82 \\
\hline & 12 & 7.75 & 9.30 & 1.74 & 8.47 & 14.9 & 18.5 & 18.5 & 13.7 & 6.53 & 0.56 & 89.3 & 9.04 \\
\hline & 14 & 9.12 & 9.00 & 2.18 & 7.72 & 15.0 & 20.0 & 12.0 & 15.3 & 9.35 & 0.45 & 68.4 & 5.74 \\
\hline & 16 & 8.92 & 10.1 & 2.86 & 6.37 & 12.1 & 21.5 & 10.1 & 15.4 & 11.4 & 1.31 & 46.1 & 4.32 \\
\hline & 17 & 9.41 & 10.0 & 2.37 & 6.96 & 13.9 & 20.0 & 11.1 & 15.0 & 9.61 & 1.66 & 62.4 & 5.99 \\
\hline & 18 & 8.00 & 8.71 & 3.15 & 5.18 & 14.5 & 21.0 & 13.8 & 16.0 & 8.40 & 1.20 & 80.1 & 7.29 \\
\hline & 19 & 10.0 & 9.99 & 4.03 & 5.71 & 12.2 & 19.4 & 9.47 & 16.8 & 11.2 & 1.25 & 54.2 & 4.97 \\
\hline & 20 & 7.64 & 8.42 & 13.2 & 6.39 & 12.2 & 19.0 & 9.74 & 13.3 & 8.73 & 1.35 & 70.6 & 6.47 \\
\hline & 21 & 8.17 & 8.92 & 6.95 & 6.68 & 12.3 & 19.3 & 11.6 & 16.1 & 8.56 & 1.42 & 65.8 & 6.01 \\
\hline \multirow{7}{*}{$\begin{array}{l}\text { «P-stress } T \text {. } \\
\text { weissflogiii» }\end{array}$} & 0 & 6.11 & 2.90 & 6.56 & 1.40 & 23.0 & 18.6 & 15.4 & 21.4 & 4.32 & 0.34 & 169 & 16.0 \\
\hline & 1 & 8.05 & 4.87 & 3.58 & 1.57 & 20.4 & 24.8 & 16.7 & 13.0 & 6.37 & 0.69 & 97.2 & 9.57 \\
\hline & 2 & 12.3 & 6.76 & 4.61 & 2.05 & 21.2 & 13.8 & 15.5 & 15.0 & 8.36 & 0.58 & 68.5 & 7.32 \\
\hline & 5 & 11.7 & 6.06 & 7.11 & 3.44 & 17.3 & 14.8 & 14.0 & 14.1 & 11.1 & 0.39 & 59.3 & 7.42 \\
\hline & 6 & 13.2 & 6.24 & 9.80 & 1.78 & 15.0 & 16.4 & 7.82 & 14.8 & 14.3 & 0.62 & 46.2 & 5.67 \\
\hline & 7 & 11.2 & 6.40 & 5.79 & 3.15 & 18.1 & 20.4 & 9.66 & 14.8 & 10.2 & 0.35 & 73.4 & 9.43 \\
\hline & 8 & 12.5 & 6.31 & 8.81 & 2.29 & 15.4 & 21.1 & 9.05 & 14.0 & 10.1 & 0.48 & 44.3 & 5.96 \\
\hline
\end{tabular}




\begin{tabular}{cccccccccccccc}
9 & 16.0 & 6.58 & 10.8 & 1.39 & 11.1 & 17.3 & 6.97 & 15.8 & 13.5 & 0.61 & 34.9 & 5.76 \\
10 & 13.0 & 8.09 & 6.74 & 3.08 & 21.1 & 12.5 & 9.62 & 16.2 & 9.29 & 0.41 & 72.9 & 0 & 12.1 \\
11 & 16.5 & 8.43 & 9.22 & 1.52 & 14.3 & 12.8 & 8.09 & 17.7 & 10.2 & 1.34 & 40.5 & 6.74 & \\
12 & 14.8 & 7.99 & 8.61 & 1.91 & 14.9 & 15.5 & 9.74 & 16.2 & 8.84 & 1.55 & 49.4 & 9.16 \\
14 & 13.3 & 8.06 & 9.97 & 1.30 & 11.6 & 18.3 & 7.64 & 15.7 & 10.6 & 3.53 & 44.1 & 6.36 \\
15 & 18.2 & 7.34 & 8.22 & 1.78 & 13.3 & 14.4 & 10.2 & 15.5 & 7.93 & 3.15 & 53.7 & 9.00 \\
16 & 21.3 & 7.43 & 9.33 & 0.68 & 12.4 & 13.8 & 7.33 & 15.4 & 10.7 & 1.50 & 42.1 & 7.23 \\
17 & 18.0 & 6.50 & 7.84 & 1.13 & 14.0 & 14.3 & 11.3 & 18.4 & 7.34 & 1.22 & 56.3 & 7.45 \\
18 & 15.0 & 7.36 & 9.50 & 2.77 & 16.2 & 15.6 & 12.5 & 15.8 & 4.07 & 1.17 & 68.2 & 7.99 \\
19 & 17.4 & 5.93 & 13.1 & 1.92 & 14.2 & 17.8 & 7.61 & 14.7 & 5.60 & 1.72 & 43.2 & 7.07 \\
20 & 11.1 & 5.41 & 5.83 & 6.43 & 22.1 & 14.2 & 11.2 & 15.6 & 7.02 & 1.21 & 73.2 & 11.6 \\
21 & 14.6 & 4.69 & 10.3 & 3.49 & 15.7 & 16.4 & 8.45 & 15.74 & 8.81 & 1.86 & 32.7 & 5.00 \\
\hline
\end{tabular}


Table 3.

\begin{tabular}{|c|c|c|c|c|c|c|c|c|c|c|c|c|}
\hline \multirow[b]{3}{*}{ Kinetic parameters } & \multicolumn{5}{|c|}{ «P-replete T. weissflogii » } & & \multicolumn{6}{|c|}{ «P-stress T. weissflogii » } \\
\hline & \multicolumn{2}{|c|}{$k_{1}$} & \multicolumn{2}{|c|}{$\mathrm{C}_{2}$} & \multirow[b]{2}{*}{$R^{2}$} & & \multicolumn{2}{|c|}{$k_{1}$} & \multicolumn{2}{|c|}{$\mathrm{C}_{2}$} & \multirow[b]{2}{*}{$R^{2}$} & \\
\hline & Value & SE & Value & SE & & & Value & SE & Value & SE & & \\
\hline POC & 0.40 & 0.05 & 0.62 & $\underline{0.01}$ & 0.94 & $n=27$ & 0.19 & $0.05^{*}$ & 0.54 & 0.03 & 0.87 & $n=25$ \\
\hline PON & 0.27 & 0.02 & 0.34 & $\underline{0.01}$ & 0.98 & $n=27$ & 0.17 & $\underline{0.03}$ & 0.29 & 0.04 & 0.91 & $n=24$ \\
\hline $\mathrm{bSiO}_{2}$ & 0.02 & 0.01 & - & - & 0.94 & $n=29$ & 0.05 & $\underline{0.02}$ & - & - & 0.95 & $n=32$ \\
\hline $\mathrm{PCHO}$ & 0.15 & 0.08 & 0.55 & $\underline{0.08}$ & 0.66 & $n=22$ & 0.92 & $\underline{0.18}$ & 0.29 & $\underline{0.02}$ & 0.81 & $n=27$ \\
\hline
\end{tabular}


Table 4

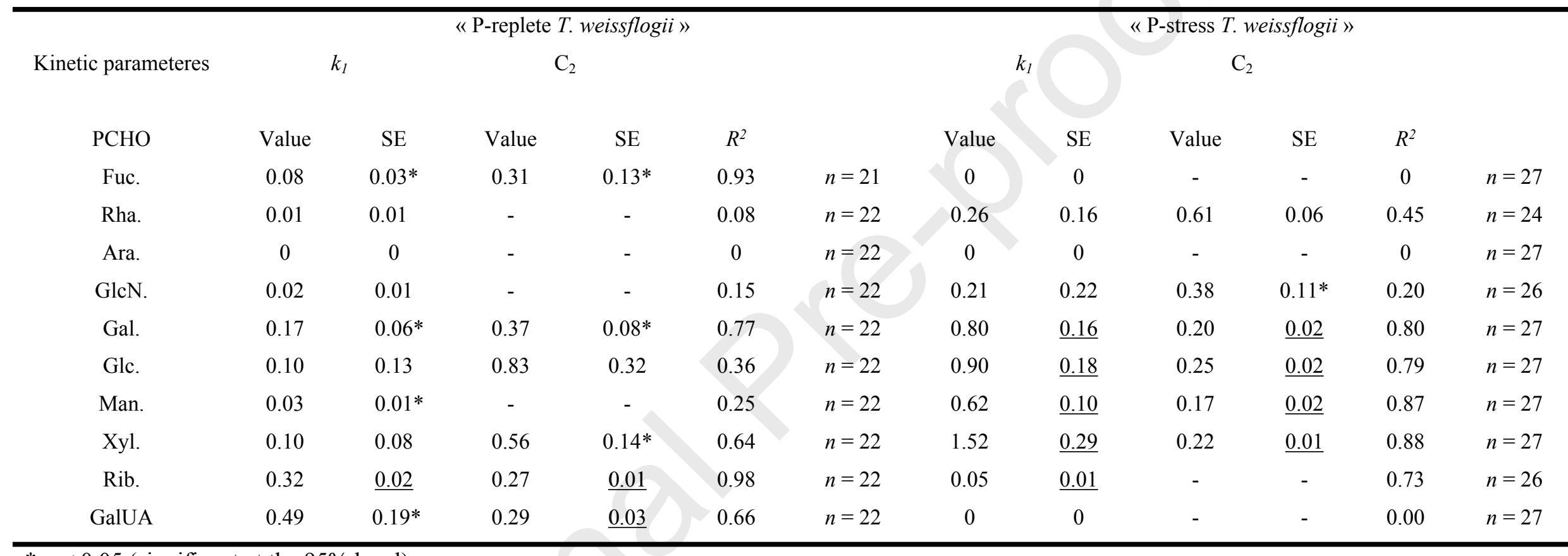

$* p<0.05$ (significant at the $95 \%$ level) 
Phosphorus limitation affects the molecular composition of Thalassiosira weissflogii leading to increased biogenic silica dissolution and high degradation rates of cellular carbohydrates

Christos Panagiotopoulos ${ }^{1 *}$, Madeleine Goutx ${ }^{1}$, Maxime Suroy $^{1}$, Brivaela Moriceau ${ }^{2}$

${ }^{1}$ Aix Marseille Univ., Université de Toulon, CNRS, IRD, Mediterranean Institute of Oceanography (MIO) UM 110, 13288, Marseille, France ${ }^{2}$ Université de Brest, Institut Universitaire Européen de la Mer (IUEM), CNRS, Laboratoire des Sciences de l'Environnement Marin, UMR 6539 CNRS/UBO/IFREMER/IRD, 29280 Plouzané, France

\section{$\underline{\text { Highlights }}$}

-Effect of P-stress on the T.weissflogii initial carbohydrate and silica composition

- High degradation of particulate organic carbon and nitrogen of T. weissflogii under Preplete conditions

-High degradation of particulate carbohydrates of $T$. weissflogii under P-stress conditions

-High dissolution of biogenic silica of T. weissflogii under P-stress conditions 